Arq. Bras. Med. Vet. Zootec., v.69, n.2, p.269-277, 2017

\title{
Biogenic amines and mycotoxins concentrations in baled silage from organic and conventional farms
}

\author{
[Concentrações de aminas biogênicas e micotoxinas em silagem \\ embalada de fazendas orgânicas e convencionais] \\ J. Jovaišiene $\dot{e}^{1}$, B. Bakutis ${ }^{1}$, V. Baliukoniene $\dot{~}^{1}$, P. Matusevičius ${ }^{1}$, K. Lipiński ${ }^{2}$, Z. Antoszkiewicz ${ }^{2}$, \\ M. Fijatkowska ${ }^{2}$ \\ ${ }^{1}$ Veterinary Academy of Lithuanian University of Health Sciences - Kaunas, Lithuania \\ ${ }^{2}$ University of Warmia and Mazury in Olsztyn - Olsztyn, Poland
}

\begin{abstract}
The aim of the current study was to investigate biogenic amines and mycotoxins concentrations in baled silage (mainly Poaceae family grasses) prepared in organic and conventional farms and to relate these parameters to fermentative parameters. The mean dry matter (DM) content was 364.10 \pm 93.31 and $424.70 \pm 95.93 \mathrm{~g} / \mathrm{kg}$ in the silage from organic and conventional farms respectively. The silage samples from organic farms had $17.00 \%$ higher $(\mathrm{P} \leq 0.05)$ tyramine $(\mathrm{TY})$ than the silage from conventional farms. Conventional farm samples were characterized by $46.00 \%$ higher histamine (HIS) (P $\leq 0.05$ ), 9.80\% higher putrescine (PUT) $(\mathrm{P} \leq 0.05), 17.30 \%$ higher cadaverine (CAD) $(\mathrm{P} \leq 0.05)$. Aflatoxins (AFL) (total) and zearalenone $(\mathrm{ZEN}), \mathrm{T}-2 / \mathrm{HT}-2$ concentrations were higher respectively $16.00 \%(\mathrm{P} \leq 0.05)$ and $13.40 \%$ $(\mathrm{P} \leq 0.05), 1.80 \%(\mathrm{P} \leq 0.05)$ in the silage prepared in organic farms. Deoxynivalenol (DON) concentration was higher $42.40 \%(\mathrm{P} \leq 0.05)$ in silage from conventional farms. Volatile fatty acids (VFA), lactic acid, ethanol, $\mathrm{pH}$ and ammonia nitrogen showed that the silage samples from organic and conventional farms were of good quality. Our study suggests differences in biogenic amine formation or mycotoxins content in silage from organic and conventional farming, but, overall, the measured values are too low to be relevant for animal health. Furthermore, these differences might as well be due to the difference in dry matter content and plant maturity between the organic and conventional silage samples.
\end{abstract}

Keywords: biogenic amines, mycotoxins, volatile fatty acids, organic farm, conventional farm

\section{RESUMO}

O objetivo do presente estudo foi investigar concentrações de aminas biogênicas micotoxinas em silagem embalada (principalmente gramíneas da família Poaceae) preparada em fazendas orgânicas e convencionais e

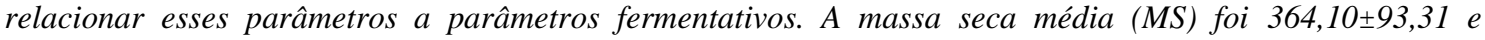
$424,70 \pm 95,93 \mathrm{~g} / \mathrm{kg}$ na silagem de fazendas orgânicas e convencionais, respectivamente. As amostras de silagem de fazendas orgânicas tinham $17 \%$ a mais de tyramina $(T Y)(p \leq 0,05)$ que as de fazendas convencionais. As amostras de fazendas convencionais foram caracterizadas por histamina (HIS) 46,00\% mais alta $(P \leq 0,05)$, 9,80\% putrecina (PUT) mais alta $(P \leq 0,05), 17,30 \%$ de cadaverina $(C A D)$ mais alta $(P \leq 0,05)$. Aflatoxnas (AFL) (total) e zearalenone (ZEN), T-2/HT-2 tinham concentrações mais altas em respectivamente 16,00\% $(P \leq 0,05)$ e 13,40\% (P $\leq 0,05), 1,80 \%(P \leq 0,05)$ na silagem preparada em fazendas orgânicas. Deoxinivalenol $(D O N)$ tinha concentração mais alta $42,40 \%(P \leq 0,05)$ na silagem de fazendas convencionais. Ácidos graxos voláteis $(A G V)$, ácido lático, etanol, $p H$ e nitrogênio de amônia mostraram que as amostras de silagem de fazendas orgânicas e convencionais tinham boa qualidade. Nosso estudo sugere diferenças na formação biogênica de amônia ou micotoxinas em silagem de fazendas orgânicas ou convencionais mas, em geral, os valores medidos foram muito baixos para serem relevantes à saúde animal. Ademais, essas diferenças podem ser devido à diferença na matéria sólida e maturidade da planta entre as amostras de silagem orgânica e convencional.

Palavras chave: aminas biogênicas, micotoxinas, ácidos graxos voláteis, fazenda orgânica, fazenda convencional

Recebido em 23 de junho de 2016

Aceito em 23 de junho de 2016

E-mail: jurgita.jovaisiene@1smuni.lt 


\section{INTRODUCTION}

The main herbage, legumes and legume - grasses are used for cattle feed in Lithuania and these plants' ensilage ensure a uniform level of animal feed year-round (Vrotniakienè and Jatkauskas, 2005). Making silage in the bales is popular both in organic and conventional farms.

A comparative study in Italy on the preservation of lucerne or grass from natural pastures showed that wrapped balls contain more mycotoxins than hay made with the same forage. Considering such a result and the large use of the wrapped ball technique during the last decade, more research on the risk associated with this type of preservation is imperative (Tomasi et al., 1999; Yiannikouris and Jouany, 2002). In Lithuania, during 2008 and 2009, compared silage was produced according to different technologies and the contamination with AFL (total) and DON concentrations were detected at $14.0 \%(\mathrm{P}>0.05)$ and $24.0 \%(\mathrm{P}>0.05)$ higher in silage from bales. ZEN concentration was detected at $3.0 \%$ $(\mathrm{P}>0.05)$ less in silage from bales than from trenches (Baliukonienè et al., 2012).

The challenge from undesirable microorganisms, such as mould, can be relatively high with baled silage (O'Brien et al., 2005). The preservation of silage depends on achieving strict anaerobic conditions within the silo to inhibit aerobic fungi and bacteria. The changes in environmental conditions from pre-ensiling through fermentation result in the establishment of characteristic mycoflora, mainly represented by Penicillium, Aspergillus and Fusarium species. However, during ensiling, most fungi can be eliminated (Mansfield and Kuldau, 2007). Deoxynivalenol and zearalenone are the main mycotoxins formed in silage. Their content is reduced by the activity of some lactic acid bacteria in the silage (Kalač, 2011). Boudra and Morgavi's (2008) results indicated that low dry matter at ensiling as well as prolonged storage could be a practical way to reduce or eliminate some Fusarium toxins in contaminated silages. However, there are other species, such as Aspergillus fumigatus, Penicillium roqueforti, $P$. paneum, F. oxysporum, and Monascus ruber that are able to tolerate both high levels of organic acids and carbon dioxide in addition to low availability of oxygen (Bryden, 2012; O'Brien et al., 2006; Storm et al., 2008). The fermentation pattern may affect the growth of mould and mycotoxin contamination in silages. Lactic acid and acetic acid have a limited effect on mould growth, whereas propionic acid and butyric acid seem to be more efficient as mould inhibitors. Large differences in preservation quality can be found, and different fungi found in forage may lead to a varied spectrum of toxins. (Chelia et al., 2013). The effects of mycotoxin ingestion are mainly chronic, implying hidden disorders with reduced ingestion, productivity, and fertility (Fink-Gremmels, 2008; Storm et al., 2008).

Little attention has been paid to the content of different protein end-products in silage and their effect on animal organisms. In literature, not much data can be found on the presence of biogenic amines in silage. The data do not reveal the composition of plants, the technology used and the effect of additive on biogenic amines. All biogenic amines served as factors significantly decreasing intake (Olt et al, 2005). In low concentrations, they are essential for the normal growth and differentiation of cells, but in larger quantities are harmful to humans and livestock (Fusi et al., 2004).

Biogenic amines are low molecular weight organic bases present in all organisms. The most common are putrescine, cadaverine, spermine, spermidine, histamine, tryptamine and phenylethylamine (Bardócz et al., 1995). Biogenic amines are naturally present in silage; however, their presence in high concentrations may be a sign of undesirable changes in the fermented forage and has been linked to low feed intake in ruminants (Van Os et al., 1996, 1997; Gąsior and Brzóska, 1999). The most common biogenic amines in silage are putrescine, histamine and tyramine. Studies have proven (Harrison et al., 1994) that biogenic amines have negative impact on dry matter intake as they inhibit ruminal contractions, reduce dry matter digestibility and the passage rate of feed particles in the digestive tract (Phuntsok et al., 1998). Amine formation can be reduced by restriction of fermentation in the silage or by achieving rapid acidification during the first phase of ensiling (Van Os et al., 1996). Formation of BA can be affected by several factors such as temperature, rapidity of $\mathrm{pH}$ decrease during the initial stage-of fermentation and oxygen availability (Dunière $e t$ al., 2013). 
Mycotoxins have been reported in organic produce. One theory is that organically-grown products are likely to contain higher concentrations of mycotoxins than conventionally-grown products (Tamm et al., 2002). However, the common argument that the ban of synthetic fungicides leads to a higher incidence of mould on organically cultivated crops and, therefore, to a higher risk of mycotoxins cannot be confirmed by the reviewed investigations comparing the mycotoxin contents of organic and conventional produce. In some investigations, even lower infestation rates of organically grown cereals with seed pathogens as Fusarium spp. and mycotoxins contamination were found than in conventional cereals treated with pesticides (Dabbert et al., 2000). Recent meta-analyses of the literature demonstrated that organic yields of individual crops are similar to those of conventionally managed crops when good management practices are applied (Seufert et al., 2012).

The aim of the present study was to investigate biogenic amines and mycotoxins concentrations in baled silage from organic and conventional farms and to relate these parameters to silage fermentative parameters.

\section{MATERIALS AND METHODS}

A total of 20 round baled silage samples (3 months after ensiling) were collected from 20 different farms in Lithuania, ten samples from organic and ten samples from conventional farms. The sampling sites were located all over the country: from the central, western, southern parts (of the country). The silage samples were taken from the centre immediately after opening the bale for feed. From one bale three samples from different places were taken and a mixed sample was made. The samples were transported in polyethylene bags with a minimum air level. The samples were frozen immediately at $-20^{\circ} \mathrm{C}$ and kept until the beginning of the laboratory analyses.

The silage was preserved by spontaneous fermentation, without biological additives. In both farm groups, silage samples were made from the first cut Poaceae - Fabaceae. The mixture of plants was rich in Poaceae grasses: perennial ryegrass, fescue grass with low count of timothy or cocks-foot and undersowed with red clover. The silage samples were wilted for about $24 \mathrm{~h}$.

The dry matter (DM) was analyzed on the day of sampling. In order to determine dry matter, the samples were chopped in $4 \mathrm{~cm}$-diameter-particles and dried for 18 hours at $55^{\circ} \mathrm{C}$. After the air equilibration, the samples were weighed and then dried again for 6 hours at $105^{\circ} \mathrm{C}$. Chemical composition (crude protein (CP), water soluble carbohydrates (WSC), neutral and acid detergent fiber (NDF and ADF)) were analyzed by Near Infrared Reflectance Spectroscopy (NIRS-6500) (AOAC, 2005).

The level of $\mathrm{pH}$ was measured in diluted silage with a pH-meter (WTW@inoLab pH 720, Germany) fitted with a glass electrode after homogenization of $10 \mathrm{~g}$ silage with $40 \mathrm{ml}$ of distilled water. Ammonia nitrogen content was determined by the Convay's micro-diffusion method.

The concentrations of VFA, lactic acid and ethanol content were determined in silage extract by high performance liquid chromatography (HPLC) according to Kostulak-Zielińska and Potkański (2001), Gąsior (2002). The fresh silage samples were homogenized in a manual blender (Bosch), in an ice bath (for $2 \mathrm{~min}$ ), pouring in five times more water than the weight of the given sample. The homogenate was filtered by straining through miller gauze; the filtrate was passed through a soft filter (Filtrak No. 388), deproteinised with $24 \%(\mathrm{w} / \mathrm{v})$ metaphosphoric acid (FLUKA) and centrifuged (7min., 10000x g at $\left.4^{\circ} \mathrm{C}\right)$ in an MPW-350R centrifuge. The supernatant was filtered (0.22-m PTFE syringe filter 30-SF-02 CHROMACOL LTD) and analysed by a SHIMADZU HPLC system, RP, column: METACARB 67H (ORGANIC ACIDS COLUMN, Varian), mobile phase: $0.002 \mathrm{M}(\mathrm{v} / \mathrm{v})$ sulphuric acid solution (95\%, Sigma-Aldrich) in deionised water, flow rate $1 \mathrm{~cm}^{3} / \mathrm{min}$., loop 201 , detector SDP-20A UV/Vis - 210nm). The external-standard method was employed using the FLUKA lactic acid standard and the SUPELCO standards of acetic, propionic and butyric acids. A mixture of standards was prepared: lactic acid $3 \mathrm{mg} / \mathrm{cm}^{3}$, acetic acid $0.5 \mathrm{mg} / \mathrm{cm}^{3}$, propionic acid $0.495 \mathrm{mg} / \mathrm{cm}^{3}$, isobutyric acid $0.5 \mathrm{mg} / \mathrm{cm}^{3}$, butyric acid $0.482 \mathrm{mg} / \mathrm{cm}^{3}$, isovaleric acid $0.463 \mathrm{mg} / \mathrm{cm}^{3}$ and valeric acid $0.469 \mathrm{mg} / \mathrm{cm}^{3}$ The peak areas from 
the sample were compared with the peak areas from the standards.

The amounts of biogenic amines were determined by high-performance liquid chromatography using the Shimadzu HPLC system according to Joosten and Olieman (1985), Gąsior and Brzóska (1999). The extraction of the amines: $50 \mathrm{~g}$ ground silage sample (robot coupe $\AA$ Blixer ${ }^{\circledR}$ 3) was homogenized in a manual blender (Bosch), in an ice bath and $250.0 \mathrm{~cm}^{3}$ distilled water (for $2 \mathrm{~min}$.). A portion of the filtrate $\left(5 \mathrm{~cm}^{3}\right)$ of this suspension was mixed with $0.5 \mathrm{~cm}^{3} 55 \%(\mathrm{w} / \mathrm{v})$ of trichloroacetic acid (TCA) and centrifuged for $10 \mathrm{~min}$ at $10000 \mathrm{x} \mathrm{g}$ and $4{ }^{\circ} \mathrm{C}$. After centrifuging the supernatant was filtered (0.22-m PTFE syringe filter 30-SF-02 CHROMACOL LTD). High-performance liquid chromatography (HPLC) Shimadzu system (RP) with a Nucleosil-C18 250/4 column, post-column derivatization with ninhydrin at the temperature of $145^{\circ} \mathrm{C}$, the phase of the carrier on the basis of DMSO, UV-VIS detector 546nm, and the patterns of biogenic amines SIGMA (Joosten and Olieman, 1986; Gąsior and Brzóska, 1999).

All the silage samples were air-dried, ground to pass a $1 \mathrm{~mm}$ screen and homogenized. The direct competitive ELISA was used for mycotoxin analysis. The principle of the test is the antigenantibody reaction. The competitive assay format, in which the toxin competes with the enzyme conjugated to the toxin for specific immobilized antibodies, is often used in commercial available kits (Ridascreen, Aflatoxin Cup, etc.). Bound enzyme conjugate converts the substrate into a colored, fluorescent or chemiluminescent active product (Gheorghe et al., 2008).

The contamination with total aflatoxins (AFL), deoxynivalenol (DON), zearalenone (ZEN) and T-2 toxin/HT-2 toxin was tested. The Veratox test kits (Neogen Corporation, Scotland), approved by the AOAC Research Institute (Certificate No. 950702), were used for the analysis. The extraction of samples was carried out in distilled water for DON and in methanol:water $(70: 30 \mathrm{v} / \mathrm{v})$ for AFL, ZEN. To ensure the accuracy of subsequent testing, excessively acidic samples were adjusted with $1 \mathrm{~N} \mathrm{NaOH}$ (sodium hydroxide) to 6.5-7.5. The extracts were filtered through Neogen filter syringes and a Whatman \#1 filter. The tests were performed according to the manufacturer's instructions. The results were obtained by measuring absorbance and were determined using the micro well strip reader (Neogen, USA) at $650 \mathrm{~nm}$ and comparing the readings against a standard curve.

The statistical analyses were carried out using SPSS software (version 17.0 for Windows, SPSS Inc., Chicago, IL, USA). Descriptive statistic and Independent-Student's t test were used to analyze the data, and the differences were considered significant at $\mathrm{P} \leq 0.05$. Furthermore, Pearson correlation coefficient between silage fermentation quality parameters and the individual amine and mycotoxins contents were calculated.

\section{RESULTS}

The quality of the observed silage in both farm groups was found within the typical range for Lithuania throughout the years. Table 1 corresponded to the value characteristics of the silage quality.

Different distribution of the amine concentrations was found between farms: $17.00 \%(\mathrm{P} \leq 0.05)$ higher levels of TY were observed in silage samples from organic farms and HIS - 46.00\% $(\mathrm{P} \leq 0.05)$, PUT - 9.80\% (P $\leq 0.05), \quad \mathrm{CAD}-$ $17.34 \%(\mathrm{P} \leq 0.05)$ higher levels - in samples from conventional farms.

Aflatoxins (total) and zearalenone, T-2/HT-2 toxin concentrations were higher respectively $15.95 \%(\mathrm{P} \leq 0.05)$ and $13.35 \%(\mathrm{P} \leq 0.05), 1.80 \%$ $(\mathrm{P} \leq 0.05)$ in silage prepared in organic farms. Deoxynivalenol concentration was higher $42.4 \%$ $(\mathrm{P} \leq 0.05)$ in silage made in conventional farms.

Correlation coefficients between biogenic amines, mycotoxins and silage fermentative parameters are given in Table 2. The statistical evaluation of the data from our samples from both farm groups showed that many correlations between the quality of silage fermentation and the concentrations of amines and mycotoxins were significant at $\mathrm{P} \leq 0.05$ or $\mathrm{P} \leq 0.01$. Particularly significant, strong positive correlations were detected between the concentrations of tyramine, putrescine, cadaverine, and the concentration of ammonianitrogen $(\mathrm{N})$, dry matter, crude proteins also with butyric acid. However, histamine concentration was not correlated with all chemical and 
fermentation parameters. Significant, negative strong correlations - between the concentrations of AFL (total) and ZEN and the concentration of dry matter, $\mathrm{pH}$ values. Mycotoxins $\mathrm{DON}$ and
T-2/HT-2 concentrations strongly positive correlated with the ammonia-nitrogen $(\mathrm{N})$ value and lactic acid concentration.

Table 1. Chemical composition (g/kg DM), content of fermentation products $(\mathrm{g} / \mathrm{kg} \mathrm{DM})$, biogenic amines $(\mathrm{mg} / \mathrm{kg} \mathrm{DM})$ and mycotoxins $(\mu \mathrm{g} / \mathrm{kg} \mathrm{DM})$ in silage from conventional and organic farms

\begin{tabular}{|c|c|c|c|c|}
\hline & \multicolumn{2}{|c|}{ Silage from conventional farms } & \multicolumn{2}{|c|}{ Silage from organic farms } \\
\hline & Mean \pm SEM $^{1}$ & Min. - Max. ${ }^{2}$ & Mean \pm SEM $^{1}$ & Min. - Max. ${ }^{2}$ \\
\hline Dry matter $(\mathrm{g} / \mathrm{kg})$ & $423.70 \pm 30.34$ & $272.00-604.00$ & $364.10 \pm 29.51$ & $248.00-533.00$ \\
\hline Crude proteins & $223.00 \pm 79.58$ & $118.00-937.00$ & $229.50 \pm 81.56$ & $116.00-958.00$ \\
\hline NDF & $492.50 \pm 27.75$ & $349.00-634.00$ & $487.20 \pm 19.79$ & $401.00-552.00$ \\
\hline $\mathrm{ADF}$ & $339.80 \pm 10.42$ & $293.00-391.00$ & $316.40 \pm 10.84$ & $269.00-381.00$ \\
\hline Lactic acid & $66.00 \pm 13.39$ & $18.28-136.02$ & $57.88 \pm 10.07$ & $6.7-109.79$ \\
\hline Formic acid & $0.03 \pm 0.01$ & $0.00-0.11$ & $4.26 \pm 4.24$ & $0.00-21.24$ \\
\hline Acetic acid & $9.98 \pm 2.99$ & $0.00-30.82$ & $15.27 \pm 6.24$ & $1.70-64.10$ \\
\hline Propionic acid & $1.24 \pm 0.31$ & $0.08-2.80$ & $1.34 \pm 0.30$ & $0.47-3.16$ \\
\hline Butyric acid & $6.14 \pm 0.93$ & $2.71-12.28$ & $4.98 \pm 0.90$ & $0.00-8.10$ \\
\hline Cadaverine & $1722.52 \pm 504.20$ & $33.30-4787.24$ & $1422.99 \pm 696.87$ & $32.54-6636.96$ \\
\hline AFL (total) & $27.35 \pm 6.79$ & $0.00-65.00$ & $32.54 \pm 7.36$ & $0.00-70.00$ \\
\hline ZEN & $338.80 \pm 41.72$ & $135.00-520.00$ & $391.00 \pm 18.97$ & $275.00-480.00$ \\
\hline DON & $327.50 \pm 45.83$ & $125.00-625.00$ & $188.60 \pm 34.03$ & $16.00-300.00$ \\
\hline T-2/HT-2 & $110.30 \pm 11.87$ & $82.00-178.00$ & $112.30 \pm 13.47$ & $59.00-193.00$ \\
\hline
\end{tabular}

${ }^{1} \mathrm{SEM}$ - standard error of mean;

${ }^{2}$ Min-Max - minimum-maximum value

Table 2. Correlation coefficient between silage biogenic amine, mycotoxins contents and fermentation parameters in all samples from both farm groups

\begin{tabular}{|c|c|c|c|c|c|c|c|c|c|c|c|c|c|}
\hline Parameter & $\begin{array}{c}\mathrm{DM} \\
(\mathrm{g} / \mathrm{kg})\end{array}$ & $\mathrm{pH}$ & $\mathrm{NH} 3 / \mathrm{kgN}$ & $\begin{array}{c}\text { Lactic } \\
\text { acid } \\
(\mathrm{g} / \mathrm{kg})\end{array}$ & $\begin{array}{c}\text { Formic } \\
\text { acid } \\
(\mathrm{g} / \mathrm{kg})\end{array}$ & $\begin{array}{l}\text { Acetic } \\
\text { acid } \\
(\mathrm{g} / \mathrm{kg})\end{array}$ & $\begin{array}{c}\text { Propionic } \\
\text { acid } \\
(\mathrm{g} / \mathrm{kg})\end{array}$ & $\begin{array}{c}\text { Isobutyric } \\
\text { acid } \\
(\mathrm{g} / \mathrm{kg})\end{array}$ & $\begin{array}{l}\text { Butyric } \\
\text { acid } \\
(\mathrm{g} / \mathrm{kg})\end{array}$ & $\begin{array}{c}\text { Isovaleric } \\
\text { acid } \\
(\mathrm{g} / \mathrm{kg})\end{array}$ & $\begin{array}{c}\text { Valeric } \\
\text { acid } \\
(\mathrm{g} / \mathrm{kg})\end{array}$ & $\begin{array}{c}\text { Ethanol } \\
(\mathrm{g} / \mathrm{kg})\end{array}$ & $\begin{array}{c}\text { Crude } \\
\text { proteins } \\
(\mathrm{g} / \mathrm{kg})\end{array}$ \\
\hline Histamine & 0.18 & 0.08 & 0.003 & -0.25 & -0.04 & 0.07 & 0.05 & -0.02 & -0.07 & -0.15 & -0.13 & 0.15 & -0.03 \\
\hline Tyramine & $-0.54^{*}$ & 0.09 & $0.80^{* *}$ & -0.29 & -0.20 & -0.19 & 0.06 & 0.01 & 0.44 & 0.23 & -0.14 & -0.23 & $0.51^{*}$ \\
\hline Putrescine & -0.34 & 0.26 & $0.67^{* *}$ & -0.33 & 0.02 & -0.02 & 0.07 & 0.07 & 0.40 & 0.40 & -0.13 & 0.24 & $0.64^{* *}$ \\
\hline Cadaverine & -0.41 & 0.19 & $0.67^{* *}$ & -0.25 & -0.19 & -0.14 & 0.02 & -0.06 & $0.48^{*}$ & 0,18 & -0.09 & -0.25 & $0.58^{* *}$ \\
\hline AFL (total) & $-0.47^{*}$ & $-0.89^{* *}$ & -0.26 & 0.42 & -0.19 & -0.35 & 0.16 & -0.16 & 0.25 & $0.60^{* *}$ & -0.21 & -0.39 & -0.28 \\
\hline ZEN & $-0.51^{*}$ & $-0.48^{*}$ & 0.3 & 0.02 & -0.06 & -0.18 & 0.01 & 0.03 & 0.08 & $0.46^{*}$ & -0.16 & -0.32 & -0.2 \\
\hline DON & 0.35 & -0.03 & 0.41 & 0.41 & 0.05 & 0.15 & 0.43 & -0.22 & 0.003 & 0.04 & 0.20 & -0.04 & -0.19 \\
\hline T-2/HT-2 & -0.37 & -0.24 & 0.42 & 0.41 & -0.21 & -0.27 & 0.34 & -0.06 & 0.07 & $0.65^{* *}$ & -0.18 & -0.22 & -0.4 \\
\hline
\end{tabular}

$* \mathrm{P} \leq 0.05 ; * * \mathrm{P} \leq 0.05$.

\section{DISCUSSION}

Forage crop composition has a major influence on silage fermentation. The most important components are dry-matter content, sugar content and buffering capacity (Piltz and Kaiser, 2004; Wyss, 2013). The samples of silage from organic and conventional farms were collected from different localities in Lithuania, so the weather conditions such as the air temperature, precipitation, plant maturity, differences between organic and conventional fertilization, and soil quality could have influenced the quality and dry matter content of the silage. The content of mean crude proteins from the organic silage was $2.80 \%$ $(\mathrm{P} \leq 0.05)$ higher than in conventional silage. Likewise, in a Belgic study, CP content in organic farms was high despite the low $\mathrm{N}$ fertilizer input (Vliegher et al., 2008). Determined $\mathrm{pH}$ values of silage showed a slight increase of $0.82 \%(\mathrm{P} \geq 0.05)$ in the silage samples from organic farms. Among the volatile fatty acids (VFA) the lactic acid was dominant. In the present study, lactic acid was the dominant fermentation product followed by acetic acid and with smaller amounts of other VFA and ethanol in both farm groups. The content of lactic acid was $12.00 \%$ higher $(\mathrm{P} \geq 0.05)$ in silage samples 
from conventional farms, while acetic acid content was 34.64\% ( $P \geq 0.05)$ higher in the samples from organic farms. These differences could have been influenced by different DM counts, WSC, or the storage under a disruption of anaerobic conditions. Furthermore, heterofermentative lactic acid bacteria result in high levels of acetic acid (Danner et al., 2003).

Butyric acid is usually produced by Clostridium sp. as a result of contamination by soil or slurry (Danner et al., 2003). The products of this fermentation contribute to a reduction in the silage intake (Purwin et al., 2006). In our study butyric acid was detected in all silage samples from organic and conventional farms respectively $4.98 \pm 0.90 \mathrm{~g} / \mathrm{kg}$ and $6.14 \pm 0.93 \mathrm{~g} / \mathrm{kg}$. Ethanol concentration as an indicator of excessive metabolism by yeasts in the silage was detected in $40 \%$ of samples from organic farms and $60 \%$ from conventional farms, the average concentration was $2.97 \mathrm{~g} / \mathrm{kg}$ in organic farms and $2.13 \mathrm{~g} / \mathrm{kg}$ in conventional farms. The content of

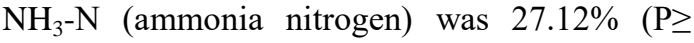
$0.05)$ higher in the samples from organic farms. A higher ammonium-nitrogen content $(>12$ to $15 \%$ of $\mathrm{CP}$ ) indicates that crude protein in the grass was degraded by undesirable microorganisms during fermentation (Downing et al., 2008). Apart from this, the silage wrapped too loosely, filled too slowly, or the delay between baling and wrapping increase the risk of high ammonia concentrations. Furthermore, clostridia not only form butyric acid but are also responsible for the degradation of proteins to ammonia (Danner et al., 2003). Purwini et al., 2009 observed that ammonium nitrogen content was higher in silage with a higher moisture content. There is not much data in literature regarding the presence of biogenic amines in silage, especially when prepared in organic farms. Biogenic amines (BA) are produced by amino acid decarboxylation due to the enzymes of several lactic acid bacteria and the species of many genera potentially present in silage such as Clostridia, Bacillus, Klebsiella, Escherichia, and Pseudomonas. The presence of BA is linked with a decrease in nutrition value and negative effects on animal health (Dunière et al., 2013). Lingaas and Tveit (1992) observed that feeding $100 \mathrm{~g}$ of putrescine a day through silage caused anorexia in some cows and not only influenced the rate of feed intake but decreased milk yield markedly. In the present study, a higher putrescine content was found $-123.62 \mathrm{mg} / \mathrm{kg}$ (i.e. mean daily intake of putrescine by an animal given $20 \mathrm{~kg}$ of silage is $2.472 \mathrm{~g}$ ) in silage produced in conventional farms. Feeding grass silage supplemented with very high level $7.2 \mathrm{~g}$ amines $/ \mathrm{kg}$ DM $(2.8,1.4,1.8$ and $1.2 \mathrm{~g}$ of TY, CAD, PUT and HI, respectively), VanOs et al. (1997) observed that in sheep non-adapted to dietary amines acutely decreased DM intake due to reduced palatability. In the present study, the level of amines was lower in both farms groups - $1.6 \mathrm{~g}$ amines $/ \mathrm{kg}$ in organic farms and $1.96 \mathrm{~g}$ amines $/ \mathrm{kg}$ in conventional farms.

The type of raw materials and environmental conditions determine the composition of epiphytic microflora on the surface of the vegetative parts of green plants, thus affecting the final microbiological quality of silage (Purwin et al., 2006). Mycotoxins are qualityimpairing toxic substances found in silage. They are produced by Fusarium spp., Aspergillus spp., Penicillium spp. fungi and can be harmful to human and animal health even in very low concentrations (Barug et al., 2004). Recommendations for maximum levels of mycotoxins in feeds and ingredients of dairy ruminants in Europe (aflatoxins have legislated maximum tolerated levels in Europe) are AFLB $_{1}$ - $0.005(\mathrm{mg} / \mathrm{kg}), \mathrm{ZEN}-0.5(\mathrm{mg} / \mathrm{kg}), \mathrm{DON}$ and T-2/HT-2 - no guidance (Tangni et al., 2013). The above analysed mycotoxins were found in all silage samples from both farming systems, but they did not exceed the recommended norm. Aflatoxins (total) and zearalenone, T-2/HT-2 concentrations were higher in silage prepared in organic farms. Deoxynivalenol concentration was higher in the silage made in conventional farms. In a German study, no significant differences were found in DON concentrations in cereal samples from organic and integrated farming systems (Mäder, 2007). In literature, not much data can be found about the presence of mycotoxins in the silage prepared in organic farms. The highest mean levels of mycotoxins: AFL (total) - $21.2 \pm 3.9 \mu \mathrm{g} / \mathrm{kg}, \quad \mathrm{DON} \quad-$ $471.0 \pm 65.6 \mu \mathrm{g} / \mathrm{kg}, \mathrm{ZEN}-397.5 \pm 83.5 \mu \mathrm{g} / \mathrm{kg}$ were detected in ryegrass silage from bales prepared in Lithuanian conventional farms during years 2008 and 2009 (Baliukoniene et al., 2012). In 2007, mycotoxins contamination in grass silage in the United Kingdom was $11.9 \mu \mathrm{g} / \mathrm{kg}$ of $\mathrm{T}-2$ and $61.8 \mu \mathrm{g} / \mathrm{kg}$ of $\mathrm{ZEN}$ toxins. Despite the small population size, these results support the idea 
that screening is of extreme importance in management due to risk of mycotoxins (Aragon et al., 2011).

A decrease in the amount of protein nitrogen during ensiling is accompanied by an increase in the content of proteolysis products, i.e. free amino acids and ammonia, as well as by the formation of biogenic amines in silage. The level of amines is negatively correlated with the rate of $\mathrm{pH}$ reduction during ensilage, and with DM intake (Steidlova and Kalač 2004, Purwini et al., 2010. Van Os et al. (1996) reported significant correlations between the concentration of total and individual content with putrescine, cadaverine and tyramine and the ammonia or acetic acid. Formation of biogenic amines in silage is related to protein degradation. In the current study, strong significant correlations were found between tyramine, putrescine, cadaverine and ammonia $(\mathrm{P}<0.05), \mathrm{CP}(\mathrm{P}<0.05)$ and butyric acid ( $\mathrm{P}>0.05)$. In 2004, Steidlova et al. reported positive correlations between the contents of putrescine and cadaverine and the contents of a-amino group and ammonia, which seem to be plausible. The Estonian researcher Olt with coworkers (2005) studied the effect of additives on the content of biogenic amines in silage. The amount of biogenic amines was very low or they were not present in wilted silages, the dry matter content of its fresh material was $310 \mathrm{~g} / \mathrm{kg}$. All biogenic amines under investigation were present in low dry matter silages without additives. Histamine had the highest and putrescine somewhat lower concentration: $5.24 \mathrm{~g} / \mathrm{kg}$ and $0.86 \mathrm{~g} / \mathrm{kg}$, respectively.

Comparing the results of our investigation to those of the Estonian researchers, a strong negative correlation between tyramine, putrescine, cadaverine, and dry matter can be seen. Fermentation pattern may affect the growth of moulds and mycotoxin contamination in silages. Lactic acid and acetic acid have a limited effect on mould growth, whereas propionic acid and butyric acid seem to be more efficient than mould inhibitors (Cheli et al., 2013). In the present study, lactic acid has strong correlations $(\mathrm{P} \geq 0.05)$ with AFL (total), DON and T-2/HT-2 and butyric acid has strong correlation $(\mathrm{P} \geq 0.05)$ with DON. Dry matter parameters showed strong negative $(\mathrm{P} \leq 0.05)$ correlations with mycotoxins. $\mathrm{PH}$ showed strong negative $(\mathrm{P} \leq 0.05)$ correlations with AFL (total) and ZEN. In the study by Boudra and Morgavi (2008) it was shown that some mycotoxins can be partially detoxified by the activity of silage fermentative bacteria. The disappearance of mycotoxins was significantly higher at a lower dry matter (280 vs. $420 \mathrm{~g} \mathrm{~kg}^{-1}$ ) and at prolonged storage $(3$ vs. 6 months), while the effect of temperatures, 15 or $30^{\circ} \mathrm{C}$, was insignificant (Kalač, 2011). The level of undissociated organic acid ( $\mathrm{pH}$ dependent) could influence the growth of mold due to the greater capacity to penetrate cell structures. The incidence of toxin metabolism under low $\mathrm{pH}$ conditions during the storage period and the toxin burden of mature silages depend on the $\mathrm{pH}$ sensitivity of different toxins (Cheli et al., 2013). The growth conditions for a specific fungal species and toxin production might differ in the field when compared with the post-harvest stages, where changes in temperature, moisture, water activity $\left(\mathrm{a}_{\mathrm{w}}\right)$ and relative humidity occur. Fungi normally grow between 10 and $40^{\circ} \mathrm{C}$, over a $\mathrm{pH}$ range of 4-8 and at $\mathrm{a}_{\mathrm{w}}$ level above 0.70 . However, it is well known that most fungi can grow in a range of conditions; furthermore, the growth on suitable substrates is not necessary for mycotoxin formation (Magan et al., 2003; Reyneri, 2006; Cheli et al., 2013).

\section{CONCLUSIONS}

Our results suggest that there are no relevant differences between organic and conventional farming systems in terms of the higher risk of contaminations of biogenic amines and mycotoxins. The results demonstrate that the concentrations of cadaverine, putrescine, and histamine were highest respectively $17.44 \%$. $(\mathrm{P} \leq$ $0.05), 9.80 \%(\mathrm{P} \leq 0.05)$ and $46.29 \%(\mathrm{P} \leq 0.01)$ in the silage from conventional farms. $100 \%$ of silage samples from organic and conventional farms contained mycotoxins (AFL (total), ZEN, DON, T-2/HT-2). In the silage from organic farms, AFL (total), ZON and T-2/HT-2 content, respectively, were higher $15.95 \% \quad(\mathrm{P} \leq 0.01)$, $13.35 \%(\mathrm{P} \leq 0.01)$ and $1.8 \%(\mathrm{P} \leq 0.05)$ than in the silage from conventional farms. DON content was $42.4 \% \quad(\mathrm{P} \leq 0.01)$ higher in silage from conventional farms. These differences might be due to a difference in dry matter content and plant maturity between the organic and conventional silage samples. Strong negative correlations between silage fermentation quality and the concentrations of amines were detected between the concentrations of tyramine, 
putrescine, cadaverine, and the concentration of ammonia-nitrogen $(\mathrm{N}), \mathrm{CP}$, butyric and strong negative correlations with DM content. Mycotoxins have strong negative correlation with DM and AFL, ZEN have strong positive correlation with $\mathrm{pH}$, and DON or T-2/HT-2 - with ammonium and lactic acid. Combined effects of biogenic amines and mycotoxins are considered to limit palatability of poorly preserved silages or to be a bad influence on livestock health. Further research is required to determine the biggest count of organic grass silage samples made in the different harvesting systems.

\section{REFERENCES}

ARAGON, Y.A.; RODRIGUES, I.; HOFSTETTER, U.; BINDER, E.M. Mycotoxins in silage: occurrence and prevention. Iran. J. Appl. Anim. Sci., v.1, p.1-10, 2011.

BALIUKONIENE, V.; BAKUTIS, B.; VAIVAODAITE, T. et al. Prevalence of fungi and mycotoxins in silage and milk in Lithuania. Vet. Med. Zootec., v.59, p.3-9, 2012.

BARDÓCZ, S.; DUGUID, T.J.; BROWN, D.S. et al. The importance of dietary polyamines in cell regeneration and growth. Br. J. Nutr., v.73, p.819-828, 1995.

BARUG. D.; VAN EGMOND, H.; LOPEZ-GARCIA, R. et al. Meeting the mycotoxin menace.[Noordwijk]: Wageningen Academic, 2004. 319p.

BOUDRA, H.; MORGAVI, D.P. Reduction in Fusarium toxin levels in corn silage with low dry matter and storage time. J. Agric. Food Chem., v.56, p.4523-4528, 2008.

BRYDEN, W.L. Mycotoxin contamination of the feed supply chain: implications for animal productivity and feed security. Anim. Feed Sci. Technol., v.173, p.134158, 2012.

CHELI, F.; CAMPAGNOLIB, A.; DELL'ORTOA, V. Fungal populations and mycotoxins in silages: from occurrence to analysis. Anim. Feed Sci. Technol. v.183, p.1-16, 2013.

DABBERT, S.; STOLZE, M.; PIORR, A.; HÄRING, A. The environmental impacts of organic farming in Europe. Org. Farming Eur. Econ. Policy. v.6, p.1-96, 2000.

DANNER, H.; HOLZER, M.; MAYRHUBER, E.; BRAUN, R. Acetic acid increases stability of silage under aerobic conditions. Appl. Environ. Microbiol., v.69, p.562-567, 2003.
DOWNING, T.W.; BUYSERIE, A.; GAMROTH, M.; FRENCH, P. Effect of water soluble carbohydrates on fermentation characteristics of ensiled perennial ryegrass. Prof. Anim. Sci., v.24, p.35-39, 2008.

DUNIÈRE, L.; SINDOU, J.; CHAUCHEYRASDURAND, F. et al. Silage processing and strategies to prevent persistence of undesirable microorganisms. Anim. Feed Sci. Technol., v.182, p.1-15, 2013.

FINK-GREMMELS J. The role of mycotoxins in the health and performance of dairy cows. Vet. J., v.176, p.84-92, 2008.

FUSI, E.; ROSSI, L.; REBUCCI, R. et al. Administration of biogenic amines to saanen kids: effects on growth performance, meat quality and gut histology. Small Ruminant Res., v.53, p.1-7, 2004.

GĄSIOR, R. Oznaczanie lotnych kwasów thuszczowych $i$ kwasu mlekowego w kiszonkach i treści żwacza. Balice, Kraków: Instytut Zootechniki, 2002.

GĄSIOR, R.; BRZÓSKA, F. The type and level of biogenic amines in alfalfa and red clover silage. Zesz. Nauk, Akad. Rolniczej Krakowie, v.347, p.89-94, 1999.

GHEORGHE, A., JECU, L., VOICU, A., POPEA, F., ROSU, A., ROSEANU, A. Biological control of phytopathogen microorganisms with antagonist bacteria, Chem. Engineering Transactions, v.14, p.509-516 2008.

HARRISON, J.H.; BLAUWIEKEL, R.; STOKES, M.R. Utilization of grass silage. Fermentation and utilization of grass silage. J. Dairy Sci., v.77, p.32093235, 1994.

JOOSTEN, H.M.L.L.; OLIEMAN, C. Determination of biogenic amines in cheese and some ather food products by HPLC in combination with thermo sensitized reaction. J. Chromatogr., v.356, p.311-319, 1986.

KALAČ P. The effects of silage feeding on some sensory and health attributes of cow's milk: a review. Food Chem., v.125, p.307-317, 2011.

KOSTULAK-ZIELIŃSKA, M.; POTKAŃSKI, A. Quality of baled grass-clover silages ensiled with chemical additives. Chemical composition. Ann. Anim. Sci., v.1, p.153-165, 2001.

LINGAAS, F., TVEIT, B. Etiology of acetonemia in Norwegian cattle. Effect of butyric acid, and putrescine. J. Dairy Sci., v.75, p.2433-2439, 1992.

MÄDER, P.; HAHN, D.; DUBOIS, D. et al. Wheat quality in organic and conventional farming: results of a 21 year field experiment. J. Sci. Food Agric., v.87, p.1826-1835, 2007. 
MAGAN, N.; HOPE, R.; CAIRNS, V.; ALDRED, D. Post-harvest fungal ecology: impact of fungal growth and mycotoxin accumulation in stored grain. Eur. $J$. Plant Pathol., v.109, p.723-730, 2003.

MANSFIELD, M.A.; KULDAU, G.A. Microbiological and molecular determination of mycobiota in fresh and ensiled maize silage. Mycologia, v.99, p.269-78, 2007.

O'BRIEN, M.; O'KIELY, P.; FORRISTAL, P.D.; FULLER, H.T. Fungi isolated from contaminated baled grass silage on farms in the Irish midlands. FEMS Microbiol. Lett., v.247, p.131-135, 2005.

O'BRIEN, M.; NIELSEN, K.F.; O'KIELY, P. et al. J. Agric. Food Chem., v.54, p.9268-9276, 2006.

OFFICIAL Methods of Analysis. 18.ed. Gaithersburg, Maryland: AOAC, 2005.

OLT, A.; KÄRT, O.; KALDMÄE, H. et al. The effect of additive and dry matter content of silage protein degradability and biogenic amine content. Estonian; University Life Scince, 2005. p.177-123. Available in: <http://agrt.emu.ee/pdf/2005_2_olt_i.pdf >. Accessed in: $25^{\text {th }}$ November 2016

PHUNTSOK, T.; FROETSCHEL, M.A.; AMOS, H.E. et al. Biogenic amines in silage, apparent postruminal passage, and the relationship between biogenic amines and digestive function and intake by steers. J. Dairy Sci., v.81, p.2193-2203, 1998.

PILZ, J.W.; KAISER, A.G. Principles of silage preservation. In: KAISER, A.G.; PILZ, J.W.; BURNS H.M.; GRIFFITHS N.W. (Eds.). Successful silage. 2.ed. Orange: Dairy Australia and NSW Department of Primary industries, 2004. p.25-59.

PURWIN, C.; ŁANIEWSKA-TROKENHEIM, Ł.; WARMIŃSKA-RADYKO， I.; TYWOŃCZUK, J. Jakość kiszonek: aspekty mikrobiologiczne, zdrowotne i produkcyjne. Med. Wet., v.62, p.865-869, 2006.

PURWIN, C.; PYSERA, B.; SEDEREVIČIUS, A. Effect of silage made from different plant raw materials with the addition of a fermentation inhibitor on the production results of dairy cows. Vet. Zootec., v.51, p.44-51, 2010.
PURWIN, C.; PYSERA, B.; TOKARCZYK, M. Production results of dairy cows fed grass alfalfa silage with a different degree of wilting. Vet. Zootec., v.46, p.60-66, 2009.

REYNERI, A. The role of climatic condition on micotoxin production in cereal. Vet. Res. Commun., v.30, Suppl.1, p.87-92, 2006.

SEUFERT, V.; RAMANKUTTY, N.; FOLEY, J.A. Comparing the yields of organic and conventional agriculture. Nature, v.485, p.229-232, 2012.

STEIDLOVA, Š.; KALAČ, P. The effects of lactic acid bacteria inoculants and formic acid on the formation of biogenic amines in grass silages. Arch. Anim. Nutr., v.58, p.245-254, 2004.

STORM, I.M.L.D.; SØRENSEN, J.L.; RASMUSSEN, R.R. et al. Mycotoxins in silage. Mycotoxins and other secondary metabolites produced in vitro by Penicillium paneum Frisvad and Penicillium roqueforti Thom isolated from baled grass silage in Ireland. Stewart Postharvest Rev., v.4, p.1-12, 2008.

TAMM, L.; THÜRIG, B. Mycotoxins and pathogens in organic food. Org. Stand., v.15, p.12-13, 2002.

TANGNI, E.K.; PUSSEMIER, L.; VAN HOVE, F. Mycotoxin contaminating maize and grass silages for dairy cattle feeding: current state and challenges. $J$. Anim. Sci. Adv. v.3, p.492-511, 2013.

TOMASI, L.; HORN, W.; RONCADA, P. et al. Recherches préliminaires sur la présenced'aflatoxine B1 dans les fourrages fanés de la province de Reggio Emilia (Italie). Fourrages, v.58, p.179-186, 1999.

VROTNIAKIENĖ, V.; JATKAUSKAS, J. Growth and carcass traits of fattening bulls offered trench or big bale silages (in Lithuanian). Anim. Husb., v.46, p.7281, 2005.

YIANNIKOURIS, A.; JOUANY, J.P. Mycotoxins in feeds and their fate in animals: a review. Anim. Res., v.51, p.81-99, 2002. 